UDC 661.961.1

\author{
V.V. Solovey ${ }^{a}$, M.M. Zipunnikov ${ }^{a}$, V.B. Poda ${ }^{b}$, I.O. Vorobjova ${ }^{a}$
}

\title{
HYDROGEN GENERATION FROM WATER BY USING ALLOYS BASED ON SILICON AND ALUMINIUM
}

\author{
${ }^{a}$ A. Pidgorny Institute of Mechanical Engineering Problems of the National Academy of Sciences of \\ Ukraine, Kharkiv, Ukraine \\ b National Aerospace University named after N.E. Zhukovsky «Kharkiv Aviation Institute», Kharkiv, \\ Ukraine
}

\begin{abstract}
We considered the process of hydrogen generation from water by using the alloys based on aluminium and silicon with the alloying additions of alkaline earth metals. The degree of completeness of the interaction between the above alloys and $\mathrm{NaOH}$ solution (10-13.3\%) was determined for the range of initial temperatures of $90^{\circ} \mathrm{C}$ to $130^{\circ} \mathrm{C}$. The required aluminium content in the ferro-silicon-aluminium alloys should be about $25-30 \%$ to intensify the hydrogen generation process in a laboratory reactor with a volume of $1.13 \cdot 10^{-3} \mathrm{~m}^{3}$. The reactions of ferro-silicon and ferro-silicon-aluminium alloys with water were investigated in an AVG-45 autonomous balloon-type gas generator. The Gibbs energy value was calculated taking into account the influence of pressure changes in the gas generator. Recommendations have been developed to apply a silicone method of hydrogen generation in the hydrogen gas generators using aluminium-silicon alloys. The interaction of aluminium-sodium hydride composites with the $\mathrm{NaH}$ content of $23 \mathrm{wt} . \%$ and $50 \mathrm{wt} . \%$ as well as the samples of sodium aluminium hydride $\left(\mathrm{NaAlH}_{4}\right)$ with water was studied to use them in the hydrogen gas generators. The procedure of hydrogen generation by means of hydro-reactive substances was adopted as a basic one to use in the hydrogen generation systems and in the developed system of hydrogen storage and hydrogen supply in experimental samples of the autonomous lifting installations.
\end{abstract}

Keywords: ferrosilicon, ferrosilicon-aluminium, hydrogen, water, aluminium hydride.

DOI: $10.32434 / 0321-4095-2020-131-4-148-156$

\section{Introduction}

Expansion of the hydrogen application areas is associated with the qualitative changes currently taking place in the chemical, machine building, metallurgical and energy industries.

Ferrosilicon alloy FS 75 (Fe 20-25, Si 74-80, $\mathrm{Al} 0.6, \mathrm{Cr} 0.5, \mathrm{P} 0.05$, and $\mathrm{S} \mathrm{0.03)}$ is used in a silicone method of hydrogen generation from water in weather stations and in aerostatics [1,2]. Silicon is an element that displaces hydrogen from water in the presence of caustic soda.

To date, the thermodynamics and kinetics of the interaction a caustic soda solution with different aluminium powders and aluminium activated by indium, gallium and tin have been investigated. As far as the silicon alloys is concerned, only some experiments were conducted with ferrosilicon FS 75 and ferrosilicon-aluminium alloys (FSA) obtained by alloying of pure components $[3,4]$.

The aim of this work is to study the process of interaction of the alloys based on silicon and aluminium with water for hydrogen generation, in particular in autonomous lifting installations.

\section{Experimental, results and discussion}

The silicone method of hydrogen generation is described by the following equation [5]:

$$
\mathrm{Si}+2 \mathrm{NaOH}+\mathrm{H}_{2} \mathrm{O} \rightarrow \mathrm{Na}_{2} \mathrm{SiO}_{3}+2 \mathrm{H}_{2} .
$$

According to stoichiometry, it needs to take $80 \mathrm{~g}$ of caustic soda for every $28 \mathrm{~g}$ of silicon soda. In high-pressure gas generators, the consumption of caustic soda amount can be much smaller, since sodium silicates are formed:

$$
2 \mathrm{Na}_{2} \mathrm{O} \cdot \mathrm{SiO}_{2}+\mathrm{H}_{2} \mathrm{O} \rightarrow 2 \mathrm{NaOH}+\mathrm{Na}_{2} \mathrm{O} \cdot 2 \mathrm{SiO}_{2} .
$$


As a result, free sodium hydroxide is released and sodium silicate is formed. Sodium silicate and its solutions are usually called soluble glass and liquid glass, respectively. The main characteristic of soluble glass is the number $\mathrm{n}$, which shows how many silica molecules $\left(\mathrm{SiO}_{2}\right)$ are related to one molecule of sodium oxide $\left(\mathrm{Na}_{2} \mathrm{O}\right)$. Sodium silicate with $\mathrm{n}=2 \mathrm{can}$ be further hydrolyzed to form silicates with a larger number n. Aqueous solutions of silicates can be generally represented by the formula $\mathrm{Na}_{2} \mathrm{O} \cdot \mathrm{nSiO}_{2} \cdot \mathrm{mH}_{2} \mathrm{O}$, where $\mathrm{m}$ is the number of water molecules that are the part of the silicates [6].

The study of the kinetics of hydrogen generation was performed in a laboratory reactor that provides an isochoric process $\left(\mathrm{V}=1.13 \cdot 10^{-3} \mathrm{~m}^{3}\right)$ (Fig. 1).

The hydrogen generating alloys have the following compositions (wt.\%):

A-98CaMg - Al 98.4, Ca 0.8, and $\mathrm{Mg} 0.8$;

$\mathrm{AB} 86$ - Si 5.0, Al 84, Cu 4.0, Sn 0.2, Mg 3.0,

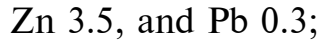

FS $75 \mathrm{Ba}$ - Fe 19.3, Si 78.4, Al 1.3, and Ba 1.0;

FS $75 \mathrm{Ba} 4-\mathrm{Fe}$ 18.1, Si 75.1, $\mathrm{Al}$ 2.0, and $\mathrm{Ba} 4.8$;

FSA $15-$ Fe 7, Si 78, and Al 15;

FSA $30-\mathrm{Fe}$ 10.3, Si 59.9, and Al 29.8;

FSA $30 \mathrm{Mn} 1$ - Fe 10, Si 56.83, Al 31.6, and Mn 1.57.

The results of the experiments are shown in Tables 1 and 2 and Figs. 2 and 3. The reaction was monitored by increasing the pressure in the reactor. The amount of the released gas was estimated by the gas meter.

The degree of conversion $\left(\alpha_{c}\right)$ was determined as the ratio of the maximum actually released

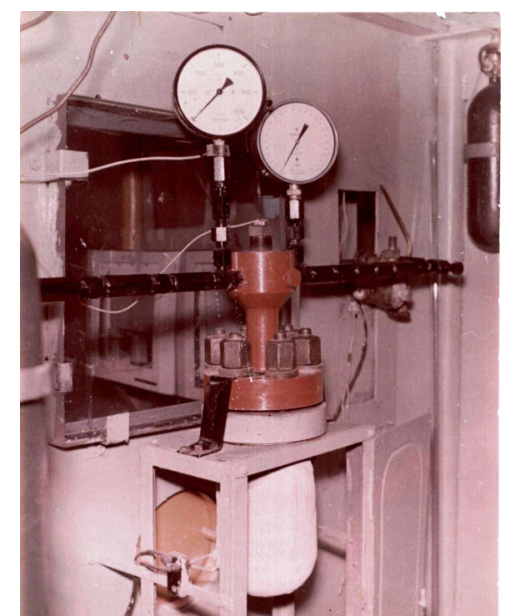

Fig. 1. Laboratory reactor with a volume of $1.13 \cdot 10^{-3} \mathrm{~m}^{3}$

hydrogen volume to the theoretically possible one:

$$
\alpha_{\mathrm{c}}=\mathrm{V}_{\mathrm{r}} / \mathrm{V}_{\mathrm{T}} \text {, }
$$

where $V_{r}$ is the volume of hydrogen that was released during the reaction and reduced to normal conditions; and $\mathrm{V}_{\mathrm{T}}$ is the theoretical volume of hydrogen released by the interaction of $\mathrm{m} \mathrm{kg}$ of pure element ( $\mathrm{Si}$ or $\mathrm{Al}$ ) with water.

For the silicon-aluminium alloys, $\mathrm{V}_{\mathrm{T}}$ was determined by the rule of additivity for the all alloy active parts.

The rate of hydrogen evolution was calculated by the following formula

$$
\mathrm{W}=\frac{\Delta \mathrm{V}}{\mathrm{m} \Delta \tau},
$$

where $\Delta \mathrm{V}$ is the volume of hydrogen released $\left(\mathrm{m}^{3}\right)$; $\Delta \tau$ is the duration of hydrogen evolution (s); and $\mathrm{m}$ is the alloy weight $(\mathrm{kg})$.

Dependence of the hydrogen evolution rate and the completeness of the reaction of FSA and FS alloys on sodium hydroxide concentration. The initial reaction temperature $t=90^{\circ} \mathrm{C}$. The alloys weight $\mathrm{m}=5 \cdot 10^{-3} \mathrm{~kg}$. The particle diameter $\mathrm{d}=(0.5-1.5) \cdot 10^{-3} \mathrm{~m}$

\begin{tabular}{l|c|c|c|c|c}
\hline \multirow{2}{*}{ Alloy type } & $\begin{array}{c}\text { Concentration of } \\
\text { sodium hydroxide, } \mathrm{wt.} \%\end{array}$ & $\begin{array}{c}\text { Maximal temperature, } \\
\mathrm{t}_{\max },{ }^{0} \mathrm{C}\end{array}$ & $\begin{array}{c}\text { Reaction time, } \\
\tau \cdot 10^{-3}, \mathrm{~s}\end{array}$ & $\begin{array}{c}\text { Maximal reactions rate } \\
\mathrm{W} \cdot 10^{3}, \mathrm{~m}^{3} /(\mathrm{kg} \cdot \mathrm{s})\end{array}$ & $\begin{array}{c}\text { Reaction } \\
\text { completeness, } \alpha\end{array}$ \\
\hline \multirow{2}{*}{ FS 75 Ba 1 } & 10 & 105 & 2.4 & 0.009 & 45 \\
\cline { 2 - 6 } & 13.3 & 104 & 1.5 & 0.16 & 60 \\
\hline \multirow{2}{*}{ FSA 30 } & 10 & 91 & 4.92 & 0.42 & 28 \\
\hline \multirow{2}{*}{ A-98CaMg } & 13.3 & 94 & 0.8 & 0.46 & 96 \\
\cline { 2 - 6 } & 10 & 105 & 0.1 & 8.7 & 99 \\
\hline \multirow{2}{*}{ AB 86 } & 13.3 & 94 & 0.9 & 3.51 & 96.4 \\
\hline
\end{tabular}


Table 2

Dependence of the hydrogen evolution rate and completeness of the reaction of FSA and FS alloys on sodium hydroxide concentration. The initial reaction temperature $t=90^{\circ} \mathrm{C}$. The alloys weight $\mathrm{m}=5 \cdot 10^{-3} \mathrm{~kg}$. The particle diameter $\mathrm{d}=(\mathbf{0 . 5}-1.5) \cdot 10^{-3} \mathrm{~m}$

\begin{tabular}{|c|c|c|c|c|c|}
\hline Alloy type & $\begin{array}{c}\text { Concentration of } \\
\text { sodium hydroxide, wt. } \%\end{array}$ & $\begin{array}{c}\text { Maximal temperature, } \\
\mathrm{t}_{\max },{ }^{0} \mathrm{C}\end{array}$ & $\begin{array}{c}\text { Reaction time, } \\
\tau \cdot 10^{-3}, \mathrm{~s} \\
\end{array}$ & $\begin{array}{c}\text { Maximal reactions rate } \\
\mathrm{W} \cdot 10^{3}, \mathrm{~m}^{3} /(\mathrm{kg} \cdot \mathrm{s})\end{array}$ & $\begin{array}{c}\text { Reaction } \\
\text { completeness, } \alpha \\
\end{array}$ \\
\hline \multirow{2}{*}{ FS 75 Ba 1} & \begin{tabular}{|r|}
10 \\
\end{tabular} & 142 & \begin{tabular}{|l|}
1.26 \\
\end{tabular} & 0.096 & 52 \\
\hline & 13.3 & 135 & 1.23 & 0.95 & 70 \\
\hline \multirow{2}{*}{ FS $75 \mathrm{Ba} 4$} & 10 & 137 & 2.4 & 0.04 & 30 \\
\hline & 13.3 & 133 & 0.37 & 0.5 & 36 \\
\hline \multirow{2}{*}{ FSA 15} & 10 & 131 & 2.6 & 0.14 & 51 \\
\hline & 13.3 & 133 & 2.9 & 0.19 & 53 \\
\hline \multirow{2}{*}{ FSA 30} & 10 & 133 & 3.66 & 2.1 & 51 \\
\hline & 13.3 & 135 & 1.68 & 3.9 & 63.6 \\
\hline \multirow{2}{*}{ FSA $30 \mathrm{Mn} 1$} & 10 & 131 & 2.2 & 0.2 & 0.4 \\
\hline & 13.3 & 132 & 2.08 & 0.16 & 0.43 \\
\hline \multirow{2}{*}{ A-98CaMg } & 10 & 132 & 0.13 & 7.8 & 99 \\
\hline & 13.3 & 134 & 0.2 & 8.1 & 99 \\
\hline \multirow{2}{*}{ AB 86} & 10 & 136 & 1.2 & 2.7 & 99 \\
\hline & 13.3 & 137 & 1.1 & 2.9 & 99 \\
\hline
\end{tabular}

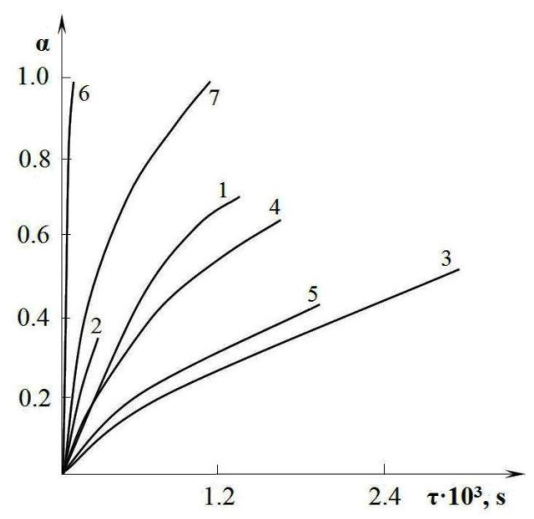

Fig. 2. Dependence of the reaction completeness on time.

The concentration of sodium hydroxide was $13.3 \%$, $\mathrm{T}_{\text {init }}=130^{\circ} \mathrm{C} .1$ - FS 75 Ba 1; 2 - FS 75 Ba 4; 3 - FSA 15; 4 - FSA 30; 5 - FSA 30Mn1; 6 - A-98CaMg; 7 - AB 86

When the temperature increases from 90 to $130^{\circ} \mathrm{C}$, the reaction rate increases significantly for the silicon-based alloys (FS 75 Bal and FSA 30), however it slightly decreases for aluminium alloys $\mathrm{A}-98 \mathrm{CaMg}$ and $\mathrm{AB} 86$. This reduction of the rate is associated with aluminium hydroxide formed on the surface of the particles. The hydrogen evolution rate for FSA 15 alloy is $\mathrm{W}_{\max }=0.19 \cdot 10^{-3} \mathrm{~m}^{3} / \mathrm{kg} \cdot \mathrm{s}$ and the reaction completeness $\alpha_{\mathrm{r}}=0.53$ (the particles size lies in the range of $(0.1-0.5) \cdot 10^{-3} \mathrm{~m}$ and the $\mathrm{NaOH}$ concentration of $13.3 \%$ ).

The $\mathrm{AB} 86$ aluminium alloy interacts with water instantly, but after a while, the resulting aluminium hydroxide begins to absorb water. Thus, the aluminium alloys require a twofold increase in water consumption. In this regard, it is desirable to limit the concentration of aluminium in FSA alloys at the level of $25-30 \%$.

An increase in the temperature to $130^{\circ} \mathrm{C}$ causes an increase in both the reaction completeness by 1.5-2,0 times and the reaction rate for the most alloys (Tables 1 and 2). The reaction products are silicon compounds of iron, barium and other impurities that can be destroyed only at elevated temperatures.

FS 75 Ba 1 alloy is much more active than FS $75 \mathrm{Ba} 4$ alloy. This is due to the fact that with increasing the aluminium content from 2 to $10 \%$ the volume of gas emission is reduced by $40-45 \%$ for the alloys containing barium $[3,4]$.

Figure 3 shows time dependences of pressure

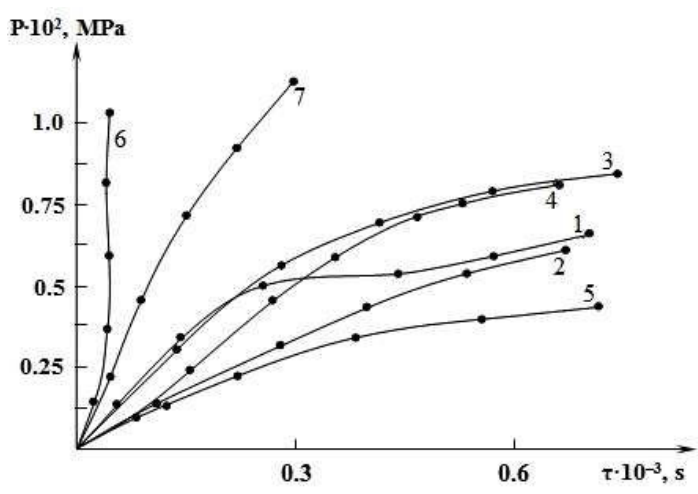

Fig. 3. Changes of pressure in the reactor with time during the interaction of alloys with $13.3 \% \mathrm{NaOH}$ solution $\left(\mathrm{m}=1 \cdot 10^{-3} \mathrm{~kg}\right)$ : 1 - FS 75 Ba 1; 2 - FS75 Ba 4; 3 - FSA 15; 4 - FSA 30; 5 - FSA 30 Mn1; 6 - A-98CaMg; 7 - AB 86 


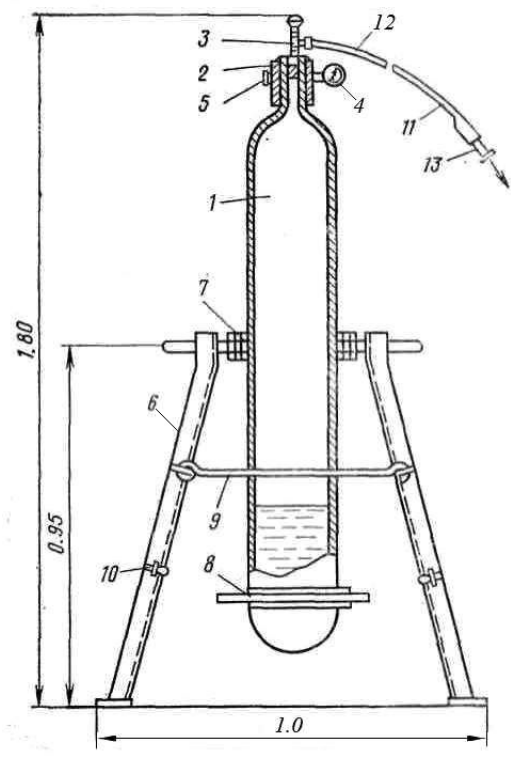

Fig. 4. AVG-45 balloon gas generator: 1 - reactor; 2 - head; 3 - valve; 4 - pressure gauge; 5 - safety valve; 6 - tripod;

7 - upper ring with a half-axis; 8 - lower ring with arms;

9 - large folding hook; 10 - small folding hook;

11 - rubberized-fabric hose; 12 - hose tip with cap nut; 13 - hose connecting branch

in the laboratory reactor during the interaction of alloys with aqueous solution of sodium hydroxide.

The reactions of the FS $75 \mathrm{Ba} 1, \mathrm{FS} 75 \mathrm{Ba} 4$, FSA 15, FSA 30 and FSA $30 \mathrm{Mn} 1$ alloys were studied in the AVG-45 industrial gas generator (Fig. 4). Before the experiments, the alloys and granular caustic soda (sodium hydroxide) powder were put into the gas generator; then the required amount of water was added.

It was found that the temperature grows from $10^{\circ} \mathrm{C}$ to $40^{\circ} \mathrm{C}$ when $0.8 \mathrm{~kg}$ of granular caustic soda was dissolved in $6 \mathrm{~L}$ of water. A further temperature increase up to $70^{\circ} \mathrm{C}$ was due to the addition of a small amount of aluminium powder, since it promotes a subsequent reaction between silicon and caustic soda.

In case of FSA $30 \mathrm{Mn} 1$ alloy, we used
$30 \cdot 10^{-3} \mathrm{~kg}$ of aluminium alloy based on $\mathrm{A}-98 \mathrm{CaMg}$ $\left(\mathrm{d}=(0.1-0.5) \cdot 10^{-3} \mathrm{~m}\right)$ to heat the reactor. This results in rapid water boiling during the first seconds of the reaction. Therefore, the amount of A-98CaMg alloy was reduced to $20 \cdot 10^{-3} \mathrm{~kg}$ in further experiments. To provide the required reaction rate and reaction completeness, the following quantities of reagents are required: $1.25 \mathrm{~kg}$ of FSA (FS), $0.8 \mathrm{~kg}$ of $\mathrm{NaOH}$, and $6 \mathrm{~L}$ of $\mathrm{H}_{2} \mathrm{O}$ [3].

The results of the study of FSA alloys and barium-containing alloys are shown in Table 3 and Fig. 5. The particle diameters were $(0.3-1.2) \cdot 10^{-3}$ $\mathrm{m},(0.1-0.52) \cdot 10^{-3} \mathrm{~m}$, and $(0.63-1.5) \cdot 10^{-3} \mathrm{~m}$ for the FS $75 \mathrm{Ba} 1 / \mathrm{FS} 75 \mathrm{Ba} 4$, FSA 30/FSA $30 \mathrm{Mn} 1$, and FSA 15 alloys, respectively.

The obtained results indicate that the highest reactor performance is observed when using the FS 75 Bal alloy. For the interaction of the FSA 30 Mn1 alloy with $13.3 \%$ solution of caustic soda in an autonomous gas generator AVG-45 of the balloon type, the reaction completeness is equal to $80 \%$, which is practically twice as much as for the laboratory experimental data $(43 \%)$ (Table 2$)$. Maximum temperatures $\left(240^{\circ} \mathrm{C}\right.$ and $\left.258^{\circ} \mathrm{C}\right)$ were detected in cases of FS $75 \mathrm{Ba}$ and FSA $30 \mathrm{Mn} 1$ alloys (Table 3).

The gas temperature in the upper part of the gas generator changes from $90^{\circ} \mathrm{C}$ to $105^{\circ} \mathrm{C}$ during the reaction and decreases up to $50^{\circ} \mathrm{C}$ at the external cooling.

It was established that it is impossible to unload the products of FSA 15 alloy interaction from the gas generator. This is partly due to a low temperature of the process. The unreacted iron- and siliconcontaining compounds are burned in the internal surface of the gas generator. The reaction products of the barium-containing alloys FS $75 \mathrm{Ba}$ and FS $75 \mathrm{Ba} 4$ are freely removed from AVG-45 gas generator due to destruction of barium silicide $\left(\mathrm{BaSi}_{2}\right)$ layer at increasing reaction temperature:

$$
\mathrm{BaSi}_{2}+5 \mathrm{H}_{2} \mathrm{O} \leftrightarrow \mathrm{BaO} \cdot 2 \mathrm{SiO}_{2}+5 \mathrm{H}_{2} .
$$

Test results of hydrogen generation in AVG-45 gas generator using FS 75 Ba1, FS 75 Ba4, FSA 15, FSA 30 and FSA 30 Mn1 alloys

\begin{tabular}{l|c|c|c|c|c}
\hline $\begin{array}{c}\text { Type of } \\
\text { alloy }\end{array}$ & $\begin{array}{c}\text { Concentration } \\
\text { of NaOH, wt.\% }\end{array}$ & $\begin{array}{c}\text { Maximum temperature in } \\
\text { the reaction zone, }{ }^{0} \mathrm{C}\end{array}$ & $\begin{array}{c}\text { Pressure in the } \\
\text { reactors, } \mathrm{MPa}\end{array}$ & $\begin{array}{c}\text { Total reaction time, } \\
\text { min }\end{array}$ & $\begin{array}{c}\text { Released hydrogen } \\
\text { volume, }^{3}\end{array}$ \\
\hline FSA 30 Mn1 & 13.3 & 258 & 5.4 & 40 & 1.31 \\
\hline FSA 30 & 13.3 & 174 & 3.75 & 58 & 1.03 \\
\hline FSA 15 & 13.3 & 164 & 3.76 & 69 & 0.97 \\
\hline FS 75 Ba1 & 10.0 & 240 & 5.62 & 25 & 1.64 \\
\hline FS 75 Ba4 & 13.3 & 145 & 4.31 & 32 & 1.14 \\
\hline
\end{tabular}




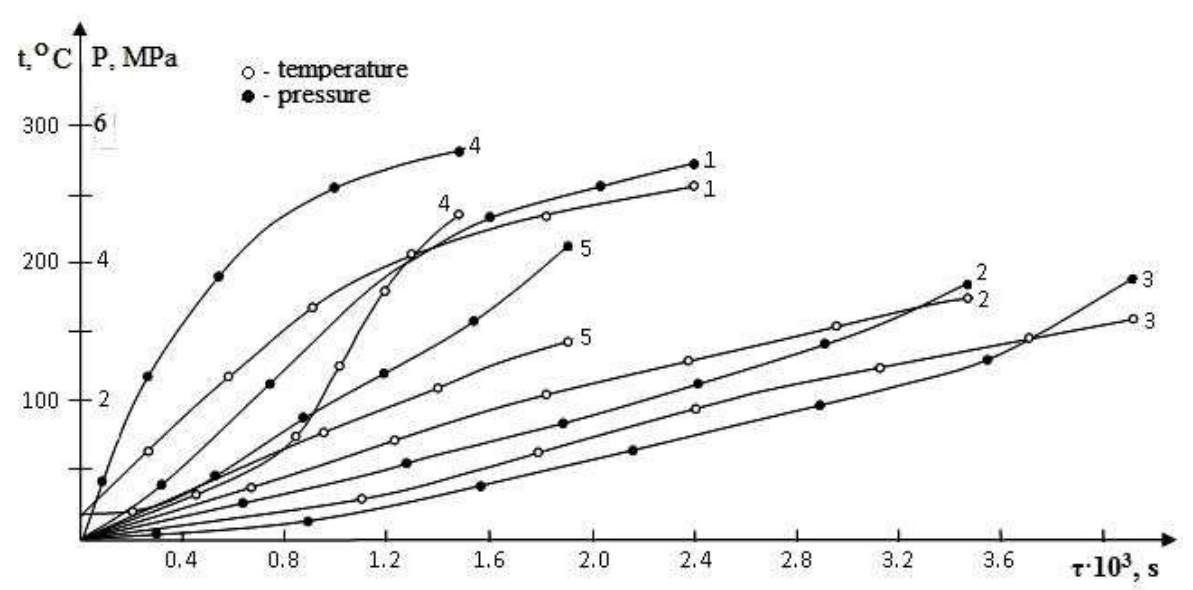

Fig. 5. Changes of pressure and temperature in the AVG-45 gas generator with time for the following alloys: 1 - FSA 30 Mn1; 2 - FSA 30; 3 - FSA 15; 4 - FS 75 Ba1; 5 - FS 75 Ba4

The possibility of chemical and phase transformations in the system is determined by the Gibbs-Helmholtz equation:

$$
\Delta \mathrm{G}=\Delta \mathrm{H}-\mathrm{T} \Delta \mathrm{S},
$$

where $\Delta \mathrm{H}$ is enthalpy change; $\Delta \mathrm{S}$ is the entropy change; and $\mathrm{T}$ is the temperature.

Since the heterogeneous reactions in our case occurs at elevated pressure, the Gibbs energy values can be are calculated taking into account the effect of pressure changes in the gas generator [7] as follows:

$$
\Delta \mathrm{G}=\Delta \mathrm{G}^{0}+\mathrm{RT} \ln \left(\mathrm{P}_{2} / \mathrm{P}_{1}\right),
$$

where $\Delta \mathrm{G}^{0}$ is the Gibbs energy in the standard state; $\mathrm{R}$ is the universal gas constant; $\mathrm{T}$ is the temperature; and $\mathrm{P}_{2}, \mathrm{P}_{1}$ are the final and initial pressure values in the apparatus, respectively.

The results of our calculations of the Gibbs energy values are given in Table 4.

The negative values of the Gibbs energy indicate the high probability of the gas evolution reactions in the course of the interaction of the considered ferrosilicon and ferrosilicon-aluminium alloys with aqueous $\mathrm{NaOH}$ solution.
It is well known that $\mathrm{Al}_{2} \mathrm{O}_{3}$ film is formed on the surface of aluminium that prevents the interaction of a metal with alkali water solution. To provide a high rate of the dissolution of aluminium, it was advisable to apply a thin layer of metallic sodium to the surface of aluminium granules. However, this will significantly complicate the procedure of reagents preparation.

Therefore, to use non-deficient components as hydro-reacting substances (HRSs) and reduce the manufacturing cost, composite HRSs were developed that are based on aluminium powder with the additives of sodium hydride $\mathrm{NaH}$ (from 23 wt.\% to 50 wt.\%). The composite was synthesized by the pressing of these components and is further referred to as aluminium-hydride-sodium composite (AHSC).

The characteristics of the interaction of the HRSs with water were studied by means of a UD40 installation (Fig. 6) at the pressure of to $4.0 \mathrm{MPa}$.

The installation UD-40 contains a reactor (1), which is fabricated in the form of a sealed steel tank with the volume of $300 \mathrm{~L}$, which is partially filled with water during the experiments. The reactor cover was equipped with an ejecting device (2) with the hydro-reacting substances samples (3) fixed, and an electrical sealed connector (4) with connected

Table 4

Thermodynamic data of the reactions between the alloys and water

\begin{tabular}{c|c|c|c}
\hline $\begin{array}{c}\text { Type of } \\
\text { alloy }\end{array}$ & $\begin{array}{c}\text { Temperature of medium in the } \\
\text { gas generator, }{ }^{0} \mathrm{C}\end{array}$ & $\begin{array}{c}\text { Gibbs energy for the standard } \\
\text { state, } \Delta \mathrm{G}^{0}, \mathrm{~kJ} / \mathrm{kg}\end{array}$ & $\begin{array}{c}\text { Specific Gibbs energy, } \\
\Delta \mathrm{G}, \mathrm{kJ} / \mathrm{kg}\end{array}$ \\
\hline FS 75 Ba1 & 45 & -5896.1 & -5865.8 \\
\hline FS 75 Ba4 & 100 & -7225.0 & -7202.9 \\
\hline FSA 15 & 70 & -9516.8 & -9488.1 \\
\hline FSA 30 & 120 & -8747.3 & -8718.6 \\
\hline FSA 30 Mn1 & 123 & -7535.5 & -7495.5 \\
\hline
\end{tabular}




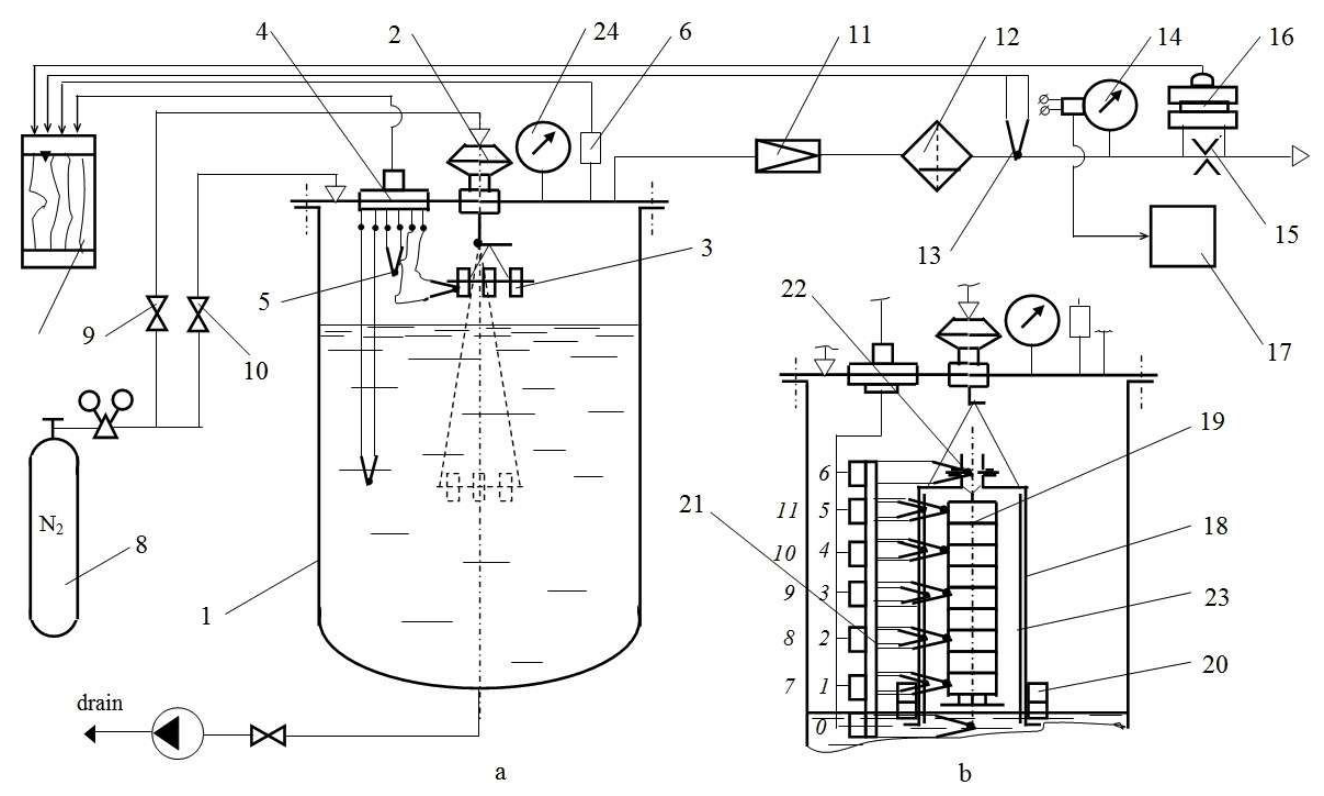

Fig. 6. Scheme of the UD-40 installation for study of the heat and mass transfer at pressures up to $4.0 \mathrm{MPa}$ : $\mathrm{a}-$ HRS and $\mathrm{b}$ - system for storage and supply of hydrogen. 1 - reactor; 2 - samples of HRS; 3 - ejecting device;

4 - electrical sealed plug; 5,13 - thermocouples; 6 - pressure sensor; 7,17 - recording devices; 8- balloon;

9 - pressure reset control stopcock; $10-\mathrm{N}_{2}$ gas purging stopcock; 11 - reducing valve; 12 - moisture removing filter;

14, 24 - manometers; 15 - diaphragm; 16 - differential pressure gauge; 18 - generator model; 19 - HRS column; 20 - ballast; 21 - thermocouple stand; 22 - throttling orifice; 23 - heat insulation

thermocouples (5) to measure water temperature in the reactor. The pressure in the reactor was controlled by the pressure gauge (21) of MP-5 type with a scale of $0-60 \mathrm{~kg} \mathrm{f} / \mathrm{sm}^{2}$ and by the pressure sensor (6) of DD-10 type. The readings were registered by a recording device (7) which was equipped with a twelve channel loop oscilloscope $\mathrm{H}-117$. The procedure for these experiments was similar to that described elsewhere [8-10].

The following AHSC samples were taken for the study: AHSC-23 containing 23 wt. $\%$ of $\mathrm{NaH}$, AHSC-50 containing 50 wt.\% of $\mathrm{NaH}$ and $5 \%$ of binder polyethylene and the samples of sodium aluminium hydride $\mathrm{NaAlH}_{4}$ (AHS).

The test samples were cylindrical elements in the form of tablets with the outer diameter of 46 $\mathrm{mm}$ and the height of $7 \mathrm{~mm}$ to $20 \mathrm{~mm}$ with a central hole having the diameter of 10 or $11 \mathrm{~mm}$. The tablets were manufactured by pressing. Their weight was ranged from $12 \mathrm{~g}$ to $35 \mathrm{~g}$.

The volume of generated hydrogen, reduced to normal conditions, was determined from the pressure drop $\Delta \mathrm{p}$ onto the diaphragm (15) according to the following equation:

$$
\mathrm{V}_{\mathrm{sp}}=0.785 \alpha \varepsilon \mathrm{d}^{2} \sqrt{\frac{2 \Delta \mathrm{p}}{\rho_{\mathrm{c}}}},
$$

where $d$ is the diameter of diaphragm aperture $(\mathrm{m})$; $\rho_{c}=\rho_{n} \frac{\left(p_{1}+p_{b}-p_{s . v}\right) T_{n}}{T_{1} p_{n}}$ is the density of dry hydrogen at the pressure $\left(p_{1}+p_{b}-p_{s . v}\right)$ and the temperature $T_{1}$ before diaphragm $\left(\mathrm{kg} / \mathrm{m}^{3}\right) ; \rho_{\mathrm{n}}$ is the density of dry hydrogen at normal pressure $\mathrm{p}_{\mathrm{n}}=0.1013 \mathrm{MPa}$ and normal temperature $T_{n}=293 \mathrm{~K}, \mathrm{~kg} / \mathrm{m}^{3} ; \mathrm{p}_{\mathrm{b}}$ and $\mathrm{p}_{\mathrm{s} . \mathrm{v}}$. are the atmospheric barometric pressure $(\mathrm{Pa})$ and saturated water vapor pressure $(\mathrm{Pa})$ at temperature $T_{1}$, respectively.

The main parameters of hydrogen evolution via interaction between aluminium-sodium HRS samples and water are shown in Table 5 and Figs. 7 and 8 .

During the performed experiments, the water temperature in the reaction vessel varied from $5^{\circ} \mathrm{C}$ to $70^{\circ} \mathrm{C}$. Nevertheless, the reaction rate remained unchanged. This indicated the external-diffusion character of the reaction mechanism. The HRSs samples reacted as the whole items with a constant rate independently of the temperature until a certain period of time. It corresponds to $\mathrm{V}_{\mathrm{sp}}=0.35-0.42 \mathrm{~m}^{3} / \mathrm{kg}$. Then, the samples fell apart and reacted further as the fine-dispersed particles.

This phenomenon indicates the transition of the reaction kinetics from the diffusion region to the kinetic one. The diffusion kinetics is typical of 
Table 5

Characteristics of hydrogen evolution via interaction between aluminium-sodium HRS samples and water reduced to normal conditions

\begin{tabular}{l|c|c|c}
\hline \multirow{2}{*}{ Characteristic } & \multicolumn{3}{c}{ Hydro-reactive substance } \\
\cline { 2 - 4 } & AHSC-23 & AHSC-50 & AHS \\
\hline Theoretical output of $\mathrm{H}_{2}$ per unit mass of $\mathrm{HRS} \mathrm{V} \mathrm{V}_{\mathrm{T}}, \mathrm{m}^{3} / \mathrm{kg}$ & 1.000 & 1.040 & 1.606 \\
\hline Experimental specific gas release $\mathrm{V}_{\mathrm{sp} .}, \mathrm{m}^{3} / \mathrm{kg}$ & $0.78 \pm 0.04$ & $0.76 \pm 0.06$ & $1.53 \pm 0.04$ \\
\hline Induction time $\tau_{\text {ind }} \mathrm{s}$ & $<0.5$ & $<0.5$ & $<0.5$ \\
\hline Rate of hydrogen evolution (with respect to surface unit) $v_{s} \cdot 10^{2}, \mathrm{~m}^{3} / \mathrm{m}^{2} \cdot \mathrm{s}$ & $72.7 \pm 0.9$ & $78.1 \pm 1.6$ & $42.5 \pm 1.5$ \\
\hline Rate of hydrogen evolution $\left(\right.$ with respect to mass unit) $v_{\mathrm{m}} \cdot 10^{2}, \mathrm{~m}^{3} / \mathrm{kg} \mathrm{s}$ & $4.33 \pm 0.2$ & $3.27 \pm 0.3$ & $2.78 \pm 0.2$ \\
\hline Rate of HRS output, $v_{1} \cdot 10^{3}, \mathrm{~m} / \mathrm{s}$ & $0.752 \pm 0.005$ & $0.673 \pm 0.008$ & $0.24 \pm 0.01$ \\
\hline Density of HRS, $\rho \cdot 10^{-3}, \mathrm{~kg} / \mathrm{m}^{3}$ & $1.24 \pm 0.06$ & $1.57 \pm 0.06$ & $1.13 \pm 0.04$ \\
\hline
\end{tabular}

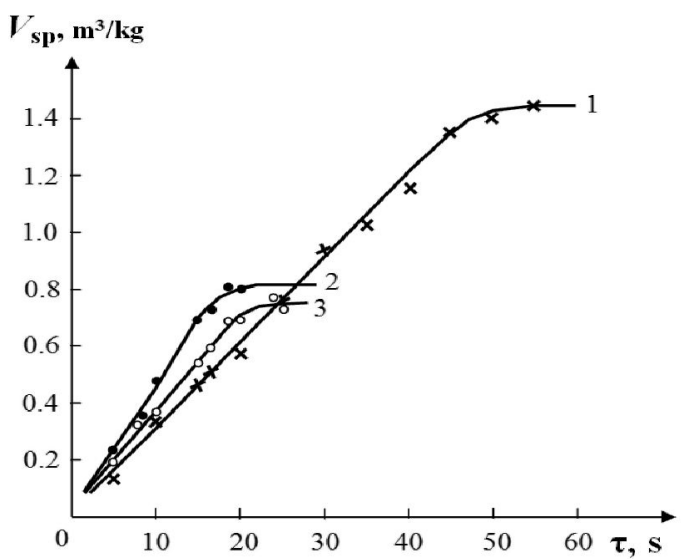

Fig. 7. Gas release generated by the aluminium-sodium HRS per unit of initial mass under normal conditions: 1 - AHS,

2 - AHSC-23, 3 - AHSC-50. Aluminium-sodium HRS samples were manufactured as tablets with the outer diameter of $46 \mathrm{~mm}$ and the thickness of $15 \mathrm{~mm}$

the samples being in a monolithic form. At the same time, the kinetic reaction region involves the reaction with the participation of scattered aluminium particles.

Study on the kinetics of reaction of aluminium hydride sodium at elevated pressure (up to $10 \mathrm{MPa}$ ) did not show any significant effect of pressure on the characteristics of the reaction with water. The limits of the experimental errors and variation did not exceed $\pm 7 \%$.

It was found that the solid insoluble reaction products of the reaction between aluminium-sodium HRSs and water are colloidal-dispersed systems having different degrees of water content. According to the data of optical microscopy, the size of the particles was $1-250 \mu \mathrm{m}$. The main bulk of these particles $(\sim 70 \%)$ were characterized by the sizes of 50-100 $\mu \mathrm{m}$. The trial experiments conducted with such samples of the aluminium-sodium HRSs showed

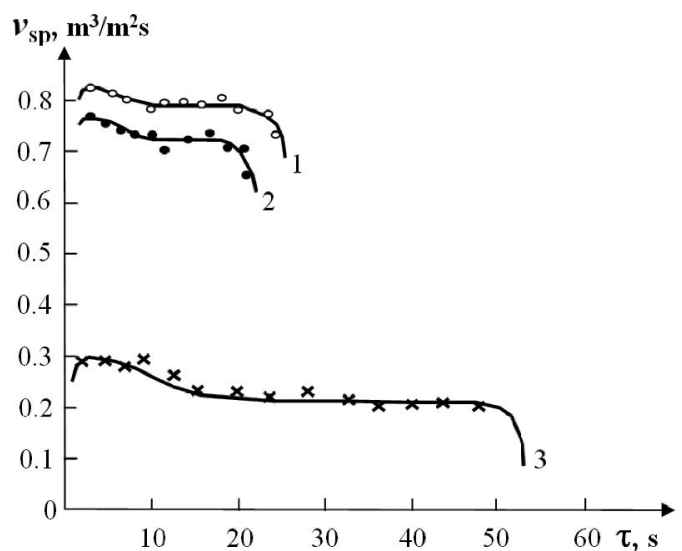

Fig. 8. Rate of hydrogen generation by the aluminium-sodium HRS per unit of initial mass under normal conditions: 1 AHS, 2 - AHSC-23, 3 - AHSC-50. Aluminium-sodium HRS samples were manufactured as tablets with the outer diameter of $46 \mathrm{~mm}$ and the thickness of $15 \mathrm{~mm}$

a high rate of their reaction with water.

The self-cost of the HRSs production is relatively low and the components of the HRSs are available products. The developed technique for hydrogen generation was adopted as a base one for the development of hydrogen storage and supply systems, in particular for the autonomous lifting devices to lift the sunken objects off the ocean bottom.

The possibility for organizing a controlled process of hydrogen generation with the help of HRSs opens the ways to create new means of travel, the principle of action of which is based on the alternating change in positive and negative buoyancy. The positive buoyancy of objects immersed in an aquatic environment can be promoted by displacing fluid by gaseous hydrogen.

\section{Conclusions}

1. With increasing the temperature from 90 to $130^{\circ} \mathrm{C}$, the reaction rate appreciably increases in case 
of the silicon-based alloys (FS 75 Ba1, FSA 30) and slightly decreases for the aluminium alloys (A-98CaMg and $\mathrm{AB}$ 86). A decrease in the rate is assoiated with the formation of aluminium hydroxide on the particles surface.

2. The highest rate and the completeness of the reaction is observed for the alloys based on aluminium (A-98CaMg and $\mathrm{AB} 86$ ). The content of aluminium in the FSA alloys should not exceed 25$30 \%$ to generate hydrogen in the balloon reactors.

3. It is impossible to unload the products of the interaction of FSA 15 alloy from the gas generator. This is partly due to a low temperature of the process. Unreacted iron-silicon compounds are burned on the internal surface of the gas generator. The products of the reaction of FS 75 Bal and FS $75 \mathrm{Ba} 4$ barium-containing alloys are freely removed from AVG-45 gas generator due to the destruction of barium silicide $\left(\mathrm{BaSi}_{2}\right)$ layer and the increase in the reaction temperature.

4. The use of alloy containing barium additives (FS $75 \mathrm{Ba}$ ) allows facilitating the removal of the reaction products, reducing the emissions of the harmful substances into the environment and simplifying the design of gas generator.

5. The solid insoluble reaction products of the reaction between aluminium-sodium HRSs and water are colloidal-dispersed systems having different water content. These samples showed a high rate of the reaction with water and satisfactory indices of specific gas evolution.

6. The self-cost of the HRSs production is low and their components are easily available products. The developed technique of hydrogen generation can be used for the development of hydrogen storage and supply systems as well as autonomous lifting devices.

\section{REFERENCES}

1. Figovskiy O.L., Beylin D.A. Nanostructured silicate polymer concrete // Vestnik MGSU. - 2014. - No. 3. - P.197204.

2. Hord $J$. Hydrogen safety: an annotated bibliography of regulations, standards and guidelines // Int. J. Hydrogen Energy. - 1980. - Vol.5. - P.579-584.

3. Zipunnikov N.N. Regularities of the heat and mass exchange under interaction of a silicon-based alloy with water in the hydrogen reactors // East. Eur. J. Adv. Technol. - 2009. No. 2/7(38). - P.52-55.

4. Thermo-gas-dynamics of physicochemical processes in alternative technologies / Rusanov A.V., Solovey V.V., Zipunnikov M.M., Shevchenko A.A. - Kyiv: Tekhnologichnyi
Tsentr, 2018. - $336 \mathrm{p}$.

5. Santos P.S., Santos H.S., Toledo S.P. Standard transition aluminas: electron microscopy studies // Mater. Res. -2000 . Vol.3. - No. 4. - P.104-114.

6. Figovskiy O.L., Beylin D.A. Improvement of strength and chemical resistance of silicate polymer concrete // Int. J. Concr. Struct. Mater. - 2009. - Vol.3. - No. 2. - P.97-101.

7. Improvement of the membrane-less electrolysis technology for hydrogen and oxygen generation / Solovey V., Nguyen T.K., Zipunnikov M., Shevchenko A. // French-Ukr. J. Chem. - 2018. - Vol.6. - No. 2. - P.73-79.

8. Microstructure and hydrogenation behavior of ball-milled and melt-spun $\mathrm{Mg}-10 \mathrm{Ni}-2 \mathrm{Mm}$ alloys / Wu Y., Han W., Zhou S.X., Lototsky M.V., Solberg J.K., Yartys V.A. // J. Alloys Compd. - 2008. - Vol.466. - No. 1-2. - P.176-181.

9. Metal hydride hydrogen compressors: a review / Lototskyy M.V., Yartys V.A., Pollet B.G., Bowman R.C. // Int. J. Hydrogen Energy. - 2014. - Vol.39. - No. 11. - P.58185851.

10. Surface-modified advanced hydrogen storage alloys for hydrogen separation and purification / Lototsky M.V., Williams M., Yartys V.A., Klochko Ye.V., Linkov V.M. // J. Alloys Compd. 2011. - Vol.509. - P.555-561.

Received 02.03.2020

\section{ГЕНЕРАЦІЯ ВОДНЮ 3 ВОДИ З ВИКОРИСТАННЯМ СПЛАВІВ НА ОСНОВІ КРЕМНІЮ І АЛЮМІНІЮ}

\section{В.В. Соловей, М.М. Зіпунніков, В.Б. Пода, І.О. Воробйова}

Розглянуто процес одержання водню з води за допомогою сплавів на основі алюмінію та кремнію з добавками лужноземельних металів. Встановлено значення ступеня завершеності реакції взаємодії сплавів, що розглядаються, з розчинами $\mathrm{NaOH}$ зі змінною концентрацією (від 10\% до 13,3\%) в інтервалі початкових температур від $90^{\circ} \mathrm{C}$ до $130^{\circ} \mathrm{C}$. Встановлено, що необхідний вміст алюмінію в феросилікоалюмінієвих сплавах повинен бути 25-30\% для того, щоб інтенсифікувати проиес виділення водню в лабораторному реакторі об'ємом $1,13 \cdot 0^{-3} \mathrm{M}^{3}$. Зі сплавами феросиліцію та феросилікоалюмінію проведено дослідження в автономному газогенераторі $A B \Gamma-45$ балонного типу. Розраховано значення енергії Гіббса з урахуванням впливу зміни тиску в газогенераторі. Надано рекомендації з застосування силіколевого способу генерації водню в водневих газогенераторах із використанням алюмокремнієвих сплавів. Здійснено дослідження алюмогідриднатріевих сумішей композитів з вмістом NaH 23 мас.\% і 50 мас.\% та зразків алюмогідрида натрію $\mathrm{NaAlH}_{4}$ з водою для застосування в водневих генераторах. Методика одержання водню з використанням гідрореагуючих речовин запропонована як базова для застосування в системах генерації водню та в розроблюваній системі зберігання і подачі водню в експериментальних зразках автономних підйомних апаратів.

Ключові слова: феросиліцій, феросилікоалюміній, водень, вода, алюмогідрид. 


\section{HYDROGEN GENERATION FROM WATER BY USING ALLOYS BASED ON SILICON AND ALUMINIUM}

V.V. Solovey ${ }^{a}$, M.M. Zipunnikov ${ }^{a,}$ ", V.B. Poda ${ }^{b}$, I.O. Vorobjova ${ }^{a}$ ${ }^{a}$ A. Podgorny Institute of Mechanical Engineering Problems of the National Academy of Sciences of Ukraine, Kharkiv, Ukraine

${ }^{b}$ National Aerospace University named after N.E. Zhukovsky «Kharkiv Aviation Institute», Kharkiv, Ukraine

* e-mail: zipunnikov_n@ukr.net

We considered the process of hydrogen generation from water by using the alloys based on aluminium and silicon with the alloying additions of alkaline earth metals. The degree of completeness of the interaction between the above alloys and $\mathrm{NaOH}$ solution (10-13.3\%) was determined for the range of initial temperatures of $90^{\circ} \mathrm{C}$ to $130^{\circ} \mathrm{C}$. The required aluminium content in the ferro-silicon-aluminium alloys should be about 25-30\% to intensify the hydrogen generation process in a laboratory reactor with a volume of $1.13 \cdot 10^{-3} \mathrm{~m}^{3}$. The reactions of ferro-silicon and ferro-silicon-aluminium alloys with water were investigated in an AVG-45 autonomous balloon-type gas generator. The Gibbs energy value was calculated taking into account the influence of pressure changes in the gas generator. Recommendations have been developed to apply a silicone method of hydrogen generation in the hydrogen gas generators using aluminium-silicon alloys. The interaction of aluminium-sodium hydride composites with the $\mathrm{NaH}$ content of $23 \mathrm{wt} . \%$ and $50 \mathrm{wt} . \%$ as well as the samples of sodium aluminium hydride $\left(\mathrm{NaAlH}_{4}\right)$ with water was studied to use them in the hydrogen gas generators. The procedure of hydrogen generation by means of hydro-reactive substances was adopted as a basic one to use in the hydrogen generation systems and in the developed system of hydrogen storage and hydrogen supply in experimental samples of the autonomous lifting installations.

Keywords: ferrosilicon; ferrosilicon-aluminium; hydrogen; water; aluminium hydride.

\section{REFERENCES}

1. Figovskiy O.L., Beylin D.A. Nanostructured silicate polymer concrete. Vestnik MGSU, 2014, no. 3, pp. 197-204.

2. Hord J. Hydrogen safety: an annotated bibliography of regulations, standards and guidelines. International Journal of Hydrogen Energy, 1980, vol. 5, pp. 579-584.

3. Zipunnikov N.N. Zakonomernosti teplomassoobmena pri vzaimodeistvii splava na osnove kremniya $\mathrm{s}$ vodoi $\mathrm{v}$ vodorodnykh reaktorakh [Regularities of the heat and mass exchange under interaction of a silicon-based alloy with water in the hydrogen reactors]. Eastern-European Journal of Advanced Technology, 2009, no. 2/7(38), pp. 52-55. (in Russian).

4. Rusanov A.V., Solovey V.V., Zipunnikov M.M., Shevchenko A.A., Termogazodinamika fiziko-energetychnykh protsesiv $v$ alternatyvnykh tekhnologiyakh [Thermo-gas-dynamics of physicochemical processes in alternative technologies]. Tekhnologichnyi Tsentr Publishers, Kyiv, 2018. 336 p. (in Ukrainian).

5. Santos P.S., Santos H.S., Toledo S.P. Standard transition aluminas. Electron microscopy studies. Materials Research, 2000, vol. 3, no. 4, pp. 104-114.

6. Figovskiy O., Beilin D. Improvement of strength and chemical resistance of silicate polymer concrete. International Journal of Concrete Structures and Materials, 2009, vol. 3, no. 2, pp. 97-101.

7. Solovey V., Nguyen T.K., Zipunnikov M., Shevchenko A. Improvement of the membrane-less electrolysis technology for hydrogen and oxygen generation. French-Ukrainian Journal of Chemistry, 2018, vol. 6, no. 2, pp. 73-79.

8. Wu Y., Han W., Zhou S.X., Lototsky M.V., Solberg J.K., Yartys V.A. Microstructure and hydrogenation behavior of ballmilled and melt-spun $\mathrm{Mg}-10 \mathrm{Ni}-2 \mathrm{Mm}$ alloys. Journal of Alloys and Compounds, 2008, vol. 466, pp. 176-181.

9. Lototskyy M.V., Yartys V.A., Pollet B.G., Bowman R.C. Metal hydride hydrogen compressors: a review. International Journal of Hydrogen Energy, 2014, vol. 39, pp. 5818-5851.

10. Lototsky M.V., Williams M., Yartys V.A., Klochko Ye.V., Linkov V.M. Surface-modified advanced hydrogen storage alloys for hydrogen separation and purification. Journal of Alloys and Compounds, 2011, vol. 509, pp. S555-S561. 